\title{
Sticky Costs Behavior and Earnings Management
}

\author{
Alini da Silva ${ }^{1,+\infty}$ \\ ${ }^{1}$ Universidade Regional de Blumenau, Blumenau, SC, Brazil \\ Vinícius Costa da Silva Zonatto 2,2@ \\ ${ }^{2}$ Universidade Regional de Blumenau, Blumenau, SC, Brazil \\ Cristian Baú Dal Magro $3, \neq 10$ \\ ${ }^{3}$ Universidade Comunitaria da Regiao de Chapecó, Chapecó, SC, Brazil \\ Roberto Klann 4,\$(1) \\ ${ }^{4}$ Universidade Regional de Blumenau, Blumenau, SC, Brazil
}

\begin{abstract}
This study aims to analyze the relationship between cost asymmetry (Sticky Costs) behavior and earnings management practices of Brazilian companies. The methodology refers to descriptive, documentary and quantitative research. The sample comprised 160 Brazilian companies listed on BM\&FBovespa between 2008 and 2017. Multiple linear regression models were used to analyze the data. We observed that accounting profit is affected by sticky costs behavior and by earnings management practices. Total accruals and part of earnings management are explained by costs asymmetric behavior. This paper contributes to the current research on the discussion that part of earnings management can be due to sticky costs. In addition, the results show that the Dechow, Sloan and Sweeney (1995) model could consider the asymmetry of costs as an interference variable on total accruals, in order to better estimate the discretionary accruals.
\end{abstract}

Keywords: Sticky Costs; Earnings Management; Management and Financial Accounting.

\section{INTRODUCTION}

In the last decade, with the driving study by Anderson, Banker, and Janakiraman (2003), research in managerial accounting have turned to the analysis of the phenomena that interfere in the asymmetric behavior of costs, mainly regarding the occurrence of changes in the levels of organizational activities.

Weiss (2010) found that firms with asymmetric costs show a greater decline in earnings when costs increase more than sales growth, and when sales reduce and costs decrease to a lesser extent. Thus, costs are asymmetric when they increase more than the increase in sales and/or reduce to a lesser extent than the decrease in sales (WEISS, 2010). According to the author, the behavior of costs is relevant for forecasting the results, and financial analysts estimate future costs based on the estimation of profits.
Corresponding author:

† Universidade Regional de Blumenau, Blumenau, SC, Brazil

E-mail: alinicont@gmail.com

${ }^{\Omega}$ Universidade Regional de Blumenau,

Blumenau, SC, Brazil

E-mail: viniciuszonatto@gmail.com

¥ Universidade Comunitaria da Regiao

de Chapecó, Chapecó, SC, Brazil

E-mail: cristianbaumagro@gmail.com

¥ Universidade Regional de Blumenau,

Blumenau, SC, Brazil

E-mail: rklann@furb.br

Received: $01 / 10 / 2018$.

Revised: 05/10/2018.

Accepted: 06/15/2018.

Published Online: 02/13/2018.

DOI: http://dx.doi.org/10.15728/bbr.2019.16.2.6 
Traditional cost accounting proposes that variable costs should move in proportion to changes in revenues. However, according to the asymmetry of costs, the change in costs depends on the magnitude of the company's operating activities. However, there are questions about the existence of such sticky costs and whether it is appropriate that the behavior of the costs be given only by its management (PORPORATO; WERBIN, 2010).

Kama and Weiss (2013) pointed out that the behavior of costs is not only a result of the usual practices of the company but can also be the result of possible consequences of intentional adjustments of the managers, in order to meet targets on reported results. The inference of Kama and Weiss (2013) raises the questioning that asymmetry in cost behavior can be glimpsed by the managerial vision and added to the perspective of financial accounting. The behavior of costs, analyzed by the prism of financial accounting, is based on the incentives of managers to manage the slack in resources in order to meet profit targets.

In this way, the analysis of another important factor that may have an association with this sticky costs financial view, which refers to the practice of earnings management, is delimited. It occurs in companies due to the increase and/or decrease of the accounting profit according to the goals of managers, who are provided by the opportunistic behavior, both personal and linked to the organizational objectives. Earnings management occurs following the "gaps" found in accounting legislation and standards, which are used to overestimate and/or underestimate the profit disclosed to interested parties (DECHOW; SLOAN; SWEENEY, 1995).

Kama and Weiss (2013) point out that management can also be done by managing resource slack at the time of sales drop, generating asymmetry in cost behavior. Banker et al. (2016) have already related the sticky costs with accounting conservatism (quality of accounting information), whose model used for measurement has the accounting variable as a dependent variable, making sense the inclusion of sticky costs in the accounting conservative analysis model.

On the other hand, from the perspective of this research, the models of earnings management (EM) using accounting choices do not hold profit as the dependent variable but take into account the total accruals, which can result by the difference between the accounting profit and the operating cash flow. Therefore, cost allocation to CPV (cost of goods sold) can be affected by cost asymmetry, that changes the accounting profit and, in turn, influences the value of the total accruals, which may bias the results of the EM models.

We observed that the asymmetric behavior of costs could explain part of earnings management besides the intention of totally opportunistic behavior of the managers. Therefore, according to the problem of possible interconnection between cost behavior and earnings management, the following question for the research is presented: what is the relationship between asymmetric behavior of costs and the practice of earnings management? In order to solve this problem, the research aims to analyze the relationship between the sticky costs and the practice of earnings management of Brazilian companies.

Regarding the relationship of cost behavior, which arises from research on managerial accounting, with financial accounting issues, such as the management of accounting results, Banker and Chen (2006) developed a profit forecasting model that reflected cost variability in line with sales revenues and cost adherence to declines in sales.

In addition, Weiss (2010) examined the influence of sticky costs on analysts' profit forecasts, especially as to the accuracy of their predictions. Kama and Weiss (2013) explored the impact of incentives to meet profit targets on resource adjustments and cost 
BBR

16,2

193

structures. Banker et al. (2016) analyzed the sticky costs in the traditionally used models to detect accounting conservatism, establishing suggestions to correct problems of asymmetry of costs in established models, such as that by Basu (1997).

In this way, due to the motivation of the interconnection between the research topics on managerial and financial accounting, and even with respect to the quality of accounting information (BANKER et al., 2006, WEISS, 2010, KAMA; WEISS, 2016), the present research fills the gap of analysis of the relationship between the sticky costs and the practice of earnings management.

Until then, research used to analyze the EM as caused only by opportunistic practices of managers, not considering the company's usual practices regarding the adherence of organizational resources, such as the case of asymmetric cost behavior. According to Banker et al. (2016), this kind of study is important since the asymmetry of costs can be confounded by financial information intervention practices, which can distort the analysis inferences from the quality models of accounting information and even offer contradictory results that can trigger conflicts.

Thus, in order to improve the understanding of EM practices, we propose the initial development of the analysis of sticky costs in EM models. However, there is no intention in this paper to exhaust the analysis of this phenomenon, since we have used only the model by Dechow, Sloan, and Sweeney (1995). In any case, the current study intends to observe preliminary results and raise questions to guide new research, establishing the applicability of models to capture opportunistic practices, associating the EM with the sticky costs. The evidence pointed out the accounting profit behaving according to the asymmetry of costs as well as EM, and how the two phenomena of distinct areas may be intertwined.

\section{STICKY COSTS}

The traditional view of accounting segregates costs into fixed and variable, and their changes occur by the volume of business activity. Based on this view, the behavior of costs has its proportional variation to the changes of the business activities and, therefore, the understanding of how the behavior of the costs occurs, in the face of market changes and adaptations of a company's strategies to its volume of negotiations, it becomes relevant for its adequate management (ANDERSON; BANKER, JANAKIRAMAN, 2003).

However, the management accounting literature has recently addressed that cost variation does not only depend on changes in revenues, but it may stem from other external and internal factors that cause costs to be asymmetric about the organization's turnover (PORPORATO; WERBIN, 2010).

According to Kama and Weiss (2013), understanding how costs move symmetrically is of interest to researchers and accounting professionals, given the impact they have on corporate profits. The behavior of costs changes according to its type, i.e., variable costs change in proportion to sales volume, while fixed costs remain unchanged. From the economic point of view, variable costs are considered to be malleable production resources by managers in the production of goods and services. On the other hand, fixed costs are values that are generally committed to productive capacity and do not change about output, especially in the short term (BANKER; CHEN, 2006; BANKER; BYZALOV, 2014).

When costs respond asymmetrically to the increase and/or decrease of activities, this phenomenon is described as sticky costs (CANNON, 2014; BANKER et al., 2016). According to Kama and Weiss (2013), when sales fall, managers decide to remove some unusable resources; however, they avoid removing resource gaps when downtime is temporary. Thus, when there are no resources cuts in times of falling sales, the company incurs high costs of adaptation, such as the dismissal of employees. 
On the other hand, managers with interest in meeting profit targets can accelerate resource cuts even in times of temporary drop in sales. This accelerated cut in resources can have consequences for further decreases in costs. Therefore, when managers have incentives to achieve targets, they are more likely to reduce the degree of cost asymmetry (KAMA; WEISS, 2013).

In order to obtain an adequate measurement of sticky costs, the models must distinguish between variable and fixed costs, about variations in production levels (CALLEJA; STELIAROS; THOMAS, 2006). Calleja, Steliaros, and Thomas (2006) point out that when there is a decline in revenues, managers can decide to keep their costs, instead of incurring contractual ruptures (generating negotiations and fines), causing asymmetry in costs. Malik (2012) points out that the complexity between costs and activity volume refers to the fact that costs do not move at the same rate as production levels.

Anderson, Banker, and Janakiraman (2003) reported that costs of sales respond differently to the increasing and decreasing changes in the company's production levels. This fact occurs mainly due to the tenacity of dismissing employees when losses occur due to activities, a fact explained by the company's attempt to maintain its status and not to demonstrate to society that it is experiencing an adverse moment. Anderson, Banker and Janakiraman (2003) found that sales, general and administrative costs increased on average by $0.55 \%$ for every $1 \%$ increase in revenue and, on the other hand, decreased by only $0.35 \%$ when there was a reduction of $1 \%$ in revenue, demonstrating that there is asymmetric behavior in costs.

Similarly, Subramaniam and Weidenmier (2003) indicated that total costs (SG \& A and CPV) increased by $0.93 \%$ for every $1 \%$ growth in revenues, while decreasing by only $0.85 \%$ for every $1 \%$ decrease in revenues, revealing the existence of sticky costs. Finally, He, Teruya and Shimizu (2010) mention that an increase in revenues causes positive changes in costs; however, when revenues decrease, managers may sometimes be hesitant to reduce the number of employees and other resources they generate costs, allowing them to pay for adherence as a design for sticky costs.

\section{EARNINGS MANAGEMENT (EM) AND CONSTRUCTION OF HYPOTHESES}

Earnings management is a purposeful intervention in the process of financial disclosure, with the objective of acquiring a particular benefit for the agent (Schipper, 1989). Healy and Wahlen (1999) state that this process occurs when managers modify a certain judgment, related to the structuring of the financial statements or in certain accounting operations, with the purpose of changing information to be disclosed, mainly to external users, about the economic performance of the company, or to influence contracts that depend on the disclosed results.

However, the earnings management cannot be considered as accounting fraud, since it operates within the limits of the legislation, especially when the rule provides the discretion in the accounting choices, opening the opportunity for several options of the same record of a certain fact (MARTINEZ, 2006).

The practice of earnings management receives attention from academia and regulatory agencies. The Security Exchange Commission (SEC) in the late 1990s, through thenPresident Arthur Levitt, voiced concern at the University of New York's extensive use of earnings management practices by corporations (BAPTISTA, 2008).

In the Brazilian scenario, the Securities and Exchange Commission (CVM) in 2007 also expressed concern about the practice of earnings management, listing some points that companies could observe to avoid such practices, such as accounting policies; performance 
BBR

16,2

195

of the board of directors; creation of specialized committees, and others. Also, the literature approaches the importance of internal control systems for the validation of accounting information and policies used by companies (BAPTISTA, 2008).

Thus, earnings management has been analyzed both in academia and by professional bodies, due to the impact it can generate in the disclosure of accounting profit. According to Jones (1991), the management of earnings can be accomplished by various means, for example, the use of accruals, accounting methods and changes in capital structure.

According to Leuz, Nanda, and Wysocki (2003), the opportunistic practice of managing the outcome is complex to measure, mainly because it manifests itself in different ways, such as aggregate, specific accumulations and/or real activities, and the more different proxies to measure management, the more consistent the result (MARTINEZ, 2006).

In EM for real activities, managers seek to reduce or increase R\&D investments, anticipate or delay sales, reduce advertising spending or non-core expenses. Managers can also increase or decrease production, causing fixed costs to be more or less diluted in product cost, which is in line with the discussion of asymmetric cost behavior.

Management by accounting choices involves the use of accruals (accruals basis), which can be analyzed individually (specific accruals), by applying different depreciation, amortization and depletion rates, provisions, impairment losses of assets, among others; or in an aggregate manner, using statistical models such as Dechow, Sloan and Sweeney (1995) used in this study.

The concern about the research points to the fact that statistical models, used to measure the level of management of accounting results, can result in skewed information, given the presence of asymmetric behavior in costs. It means that part of the EM obtained from the aggregate accruals, based on the regression models, may contain information on cost management, aligned with management by actual choices.

This influence of cost asymmetry was already observed, for example, in profit forecasting models, whose model developed by Banker and Chen (2006), which observes the sticky costs, better represented the expectations of market profits than the other models. This same problem was studied by Weiss (2010), who examined how the asymmetric behavior of costs influences the accuracy of predictions. The findings indicated that firms with sticky costs present less accurate profit forecasts to analysts, with cost asymmetry influencing the priorities observed by analysts and investors in forming beliefs about firm value.

Kama and Weiss (2013) investigated the relationship between resource adjustments made intentionally to achieve profit goals and the degree of cost asymmetry, arguing that personal interests can also drive managers' choices for keeping unused resources. The findings showed that when managers face incentives to manipulate losses and/or reduce profits, they tend to reduce the degree of cost asymmetry, i.e., when there are incentives to manipulate results, managers decrease the degree of asymmetry of costs rather than induce their increase.

Specifically, about the quality of the accounting information, which includes the EM practices, Banker et al. (2016) analyzed the influence of cost asymmetry on the traditional models of detecting accounting conservatism. The results showed that estimates of conditional conservatism are exaggerated by more than $25 \%$, due to the existence of sticky cost's behavior. They observed that conservatism models had not controlled the effect of cost asymmetry, suggesting that future studies will neutralize the influence of asymmetric costs on the measurement of conservatism.

Also, Chen, Lu, and Sougiannis (2012) believe that the sticky costs are associated with proxies that measure agency problems. Therefore, since managerial ownership aligns 
managers' incentives with shareholder interests, it may also be associated with lower adherence to firm costs.

According to the evidence pointed out by Banker and Chen (2006), Weiss (2010), Chen, Lu and Sougiannis (2012), Kama and Weiss (2013), and Banker et al. (2016), we can infer that the allocation of production costs affects the sticky costs and, as a consequence, interferes with the value reported by the total accruals, which are used to measure the variable dependent on earnings management models through choices accounting. Therefore, although the management of earnings does not consider the profit reported as an intervening variable, it can also be affected indirectly by the different allocation of production costs.

Thus, based on the evidence from the abovementioned studies, it is assumed that the accounting profit may be affected by both operational decisions, resulting from sticky costs, and by accounting choices, such as discretionary accruals used by managers to achieve the goals of profitability and these are associated. Thus, the hypothesis of the study was delimited:

H1: The management of earnings through accounting choices is partly a result of the sticky costs.

\section{METHODOLOGICAL PROCEDURES}

The methodological design of the research is descriptive, documental and with a quantitative approach. The study population comprised all companies listed on the São Paulo Mercantile and Futures Exchange - BM\&FBovespa.

We excluded from the sample companies that did not have the information necessary for the analysis, as well as those from the "financial and other" sector, which totaled 117 companies. Financial firms were excluded because, according to Banker et al. (2016), these present different operations about sticky costs, which do not make them comparable about the other sectors analyzed.

Therefore, the final sample corresponded to 160 companies, which had the necessary data for the analysis, between 2008 and 2017 (10 years), leading to 1,600 observations. However, it was also necessary to exclude the outliers, resulting in an unbalanced sample of 1,540 observations for the model of equation 6 and 1,531 observations for the seven equation model.

Data collection used the Economática database, which sought information from the Jones (1991) and Jones Modified (1995) - Dechow, Sloan, and Sweeney (1995) earnings management models, as well as the sticky costs and control variables of the study. We present the Jones model (1991) in equation 1.

$$
T A_{i t}=\alpha\left(\frac{1}{A_{t-1}}\right)+\beta_{1}\left(\Delta R_{i t}\right)+\beta_{2}\left(P P E_{i t}\right)+v_{i t}
$$

Where:

$\mathrm{TA}_{i t}$ : accruals of company $\mathrm{i}$ in period $\mathrm{t}$, weighted by total assets at the end of period $\mathrm{t}-1$;

$\mathrm{A}_{i t-1}:$ total assets of the company at the end of period $\mathrm{t}-1$;

$\Delta \mathrm{R}_{i t}$ : change in net revenues of company $\mathrm{i}$ of period $\mathrm{t}$ for period $\mathrm{t}-1$, weighted by total assets at the end of period $t-1$;

$\mathrm{PPE}_{i t}$ : total of property, plant and equipment and deferred or intangible assets of company $i$ at the end of period $t$, weighted by total assets at the end of period $t-1$. 
BBR

16,2

197

This model was run by year and sector to obtain the estimated coefficients a, $\mathrm{p} 1$ and P2, applied later in the Modified Jones model (1995), according to equation 2, in order to estimate non-discretionary accruals using the sum of the explanatory variables.

$$
N D A_{i t}=\alpha\left(\frac{1}{A_{i t-1}}\right)+\beta_{1}\left(\Delta R_{i t}-\Delta C R_{i t}\right)+\beta_{2}\left(P P E_{i t}\right)
$$

Where:

$\mathrm{NDA}_{i t}$ : non-discretionary accruals of company $\mathrm{i}$ in period $\mathrm{t}$;

$\mathrm{A}_{i t-l}$ : total assets of the company at the end of period t-1;

$\Delta \mathrm{R}_{i t}$ : change in net revenues of company $\mathrm{i}$ of period $\mathrm{t}$ for period $\mathrm{t}-1$, weighted by total assets at the end of period $\mathrm{t}-1$;

$\Delta \mathrm{CR}_{\mathrm{it}}$ : variation of accounts receivable from company $\mathrm{i}$ of period $\mathrm{t}$ for period $\mathrm{t}-1$, weighted by total assets at the end of period $\mathrm{t}-1$;

$\mathrm{PPE}_{i t}$ : total of property, plant and equipment and deferred or intangible assets of company $i$ at the end of period $t$, weighted by total assets at the end of period $t-1$.

$\alpha, \beta 1$ and $\beta 2$ : coefficients of the Jones model regression (1991).

According to Dechow, Sloan and Sweeney (1995), to estimate discretionary accruals, which are manageable for results, we have Equation 3:

$$
A D_{i t}=T A_{i t}-N D A_{i t}
$$

Where:

$\mathrm{AD}_{\mathrm{it}}=$ discretionary accruals of the company in period $\mathrm{t}$;

$\mathrm{TA}_{i t}=$ total accruals of company $\mathrm{i}$ in period $\mathrm{t}$;

$N D A_{i t}=$ non-discretionary accruals of company $\mathrm{i}$ in period $\mathrm{t}$.

Thus, the non-discretionary accruals of the companies, obtained by the Modified Jones Model (1995), were reduced from the total accruals, calculated by the difference between the net income and the operating cash flow, obtaining the value of discretionary accruals, management of earnings, for each company analyzed and year.

The model used to observe the level of cost asymmetry per year of the companies analyzed is presented in equation 4. This model refers to Banker et al. (2016).

$$
\begin{aligned}
E_{i t} / P_{i t-1}= & \beta_{0}+\beta_{1} D S_{i t}+\beta_{2} \Delta S_{i t} / P_{i t-1}\left(\mu_{1}+\mu_{2} \text { Size }_{i t}+\mu_{3} M / B_{i t}+\mu_{4} \text { Lev }_{i t}\right) \\
& +\beta_{3} D S_{i t} X \Delta S_{i t} / P_{i t-1}\left(\lambda_{1}+\lambda_{2} \text { Size }_{i t}+\lambda_{3} M / B_{i t}+\lambda_{4} \text { Lev }_{i t}\right) \\
& +\left(\delta_{1} \text { Size }_{i t}+\delta_{2} M / B_{i t}+\delta_{3} \text { Lev }_{i t}+\delta_{4} D S_{i t} \text { Size }_{i t}+\delta_{5} D S_{i t} M / B_{i t}\right. \\
& \left.+\delta_{6} D S_{i t} L e v_{i t}\right)+\varepsilon_{i t}
\end{aligned}
$$

Where:

$\mathrm{E}_{\mathrm{it}} / \mathrm{P}_{\mathrm{it}-1}$ : profit of company $\mathrm{i}$ in period $\mathrm{t}$ spread by the market value of the shares (stock price) at the beginning of the fiscal year;

$\mathrm{DS}_{\mathrm{it}}$ : dummy variable that is equal to one if there is a fall in sales from year $\mathrm{t}-1$ to year $\mathrm{t}$ and zero otherwise;

$\Delta \mathrm{S}_{\mathrm{it}} / \mathrm{P}_{\mathrm{it}-1}$ : change in sales from year $\mathrm{t}-1$ to year $\mathrm{t}$, which is divided by the market value of the shares at the beginning of the fiscal year;

$\mathrm{DS}_{\mathrm{it} X} \Delta \mathrm{S}_{\mathrm{it}} / \mathrm{P}_{\mathrm{it}-1}:$ multiplication between the variables $\mathrm{DS}_{\mathrm{it}}$ and $\Delta \mathrm{S}_{\mathrm{it}} / \mathrm{P}_{\mathrm{it}-1}$;

Size $_{\text {it }}$ : size of the company according to the natural logarithm of market value;

$\mathrm{M} / \mathrm{B}_{\mathrm{it}}$ : market-to-book; 
$\operatorname{Lev}_{\mathrm{it}}$ : leverage measured through long-term and short-term debt deflated by market value;

$\mu_{i}$ and $\lambda_{i}$ : are constant empirical estimates for all firms, but they vary according to time, estimated by annual cross-sectional regressions.

The independent variables of equation 4 capture the sticky costs, essentially P3, which reports the negative sales variation. It shows that profit is proportionately higher about sales when they decrease more than when they increase, implying that the negative return on sales should have a positive impact on profit and then demonstrate cost asymmetry. According to Banker et al. (2016) costs are asymmetric when they rise more by the increase in sales than fall to the equivalent reductions, which is due to cost adjustments. If there is a positive return on sales, due to sticky costs, more costs would be recognized, and there is a reduction in profit, so when there is a negative return on sales, fewer costs are recognized, and there is no reduction of proportional profit what indicates a positive association between negative return on sales and profits.

With the estimators generated by Equation 4, the SC_Score was calculated using equation 5, emphasizing that this not refer to the regression model, but rather, the equation to obtain the index of asymmetry of costs for each company about the years SC-Score since $\mathrm{SC}$ refers to Sticky Costs (cost asymmetry).

$S C$ Score $_{i t}=\lambda_{1}+\lambda_{2}$ Size $_{i t}+\lambda_{3} M / B_{i t}+\lambda_{4}$ Lev $_{i t}$

Where:

SC_Score: level of cost asymmetry (Sticky Costs) per company and year;

Size $_{\text {iit }}$ : size of the company according to the natural logarithm of the market value;

$\mathrm{M} / \mathrm{B}_{\mathrm{it}}$ : market-to-book;

$\mathrm{Lev}_{\mathrm{it}}$ : leverage measured by long-term and short-term debt deflated by market value.

Banker et al. (2016) used the methodology of Khan and Watts (2009) to estimate the level of accounting conservatism per company and year and also the asymmetry of costs per company and year, in which such model included the variables of Size, MTB, and Lev for such estimates. Thus, these variables were included (Size, MTB, and Lev) in the model by Banker et al. (2016) to calculate per company, the variables' coefficients indicating the level of cost asymmetry. The variables Size, MTB, and Lev, according to Banker et al. (2016) can lead to a variation of asymmetry of costs for each company. Thus, the coefficients are estimated by equation 4 and after, multiplying them by the variables of equation 5 , and with the sum of these there is the SC_Score.

Calculating the level of earnings management, as well as of sticky costs by the previous equations per company and per year, we estimated the equation 6 , which reveals the influence of sticky costs, as well as control variables in the earnings management level of the analyzed companies.

$$
A D_{i t}=\beta_{0}+\beta_{1} S C_{-} S c o r e_{i t}+\beta_{2} T A M_{i t}+\beta_{3} E N D_{i t}+\beta_{4} R O E_{i t}+v_{i t}
$$

Where:

$\mathrm{AD}_{\mathrm{it}}$ : level of earnings management observed through equation 3;

SC_Score $e_{\mathrm{it}}$ level of cost asymmetry (Sticky Costs) observed through equation 5;

$\mathrm{TAM}_{\mathrm{it}}$ : size of the company, represented by total logarithmic assets;

$\mathrm{END}_{\mathrm{it}}$ : company's indebtedness, represented by the sum of current liabilities, plus noncurrent liabilities, divided by total assets;

$\mathrm{ROE}_{\mathrm{it}}$ : return on Shareholders' Equity. 
BBR

16,2

In addition to the variable of sticky costs, the variables of the size of the company (TAM) is presented, also, indebtedness (END) and return on equity (ROE) as possible influencers of EM practice. According to Leuz (2003) companies that are large tend to perform accounting practices, such as earnings management, in order to reduce the result.

Indebted companies tend to manage less income due to the need to report quality of accounting information to banks, in order to obtain a reduction in financing costs (BUSHMAN; CHEN; ENGEL; SMITH, 2004). On the other hand, companies that have high profitability tend to manage the result more often, since due to contracts with users, they want to maintain the level of profitability in order to maintain and attract new investors (DOYLE; GE; MCVAY, 2007; BAPTISTA, 2008).

According to equation 6, as SC_Score it refers to the variable that aims to discriminate the sticky costs, the objective was to observe if this variable has a relation with the level of discretionary accumulations (AD). We expect that the higher the level of cost asymmetry, the higher the $\mathrm{AD}$ (positive association), since part of the EM could be caused by the sticky costs.

Equation 7, characterized by the inclusion of the sticky costs variable in the original Dechow model, Sloan, and Sweeney (1995), was used to observe if the coefficients, R2, and residues of the original variables of the Dechow, Sloan model and Sweeney (1995) vary with the presence of this variable. This methodology was similarly used by Banker et al. (2016), who included the variables of sticky costs in the original model by Basu (1997), in order to capture whether part of the accounting conservatism was in reality, the sticky costs, which confirmed its hypothesis.

$$
T A_{i t}=\alpha\left(\frac{1}{A_{i t-1}}\right)+\beta_{1}\left(\Delta R_{i t}-\Delta C R_{i t}\right)+\beta_{2} P P E_{i t}+\beta_{3} S C S_{-} \text {core } e_{i t}+v_{i t}
$$

Where:

$\mathrm{TA}_{i t} ; \mathrm{A}_{i t-1} ; \Delta \mathrm{R}_{i t} ; \Delta \mathrm{CR}_{\mathrm{it}} ; \mathrm{PPE}_{i t}$ equations 2 and 3.

SC_Score $e_{\text {it }}$ level of cost asymmetry (Sticky Costs) observed by means of equation 5 .

This variable of sticky costs (SC_Score it) can contribute to the explanation of total accumulations (TA it), in addition to the original variables by Dechow, Sloan and Sweeney's (1995) model, such as revenue variation, accounts receivable and permanent assets variation, which will bring greater power of explanation to this.

Also, we considered that this model already foresees accumulations arising from revenue variation, which in the current study, we present the variation of accumulations by sticky costs, in addition to revenues. Data analysis was performed using descriptive statistics and multiple regression using STATA software.

\section{DESCRIPTION AND ANALYSIS OF RESULTS}

Table 1 shows the mean of positive and negative discretionary accumulations per year (manageable), which were calculated using equations 1, 2 and 3.

Regarding the data in Table 1, we can observe that in the years 2008 and 2010 most companies used management practices to reduce the reported earnings. Also, these companies presented a higher average of negative discretionary accruals about the average positive discretionary accruals, respectively -0.19 in 2008 and -0.15 in 2010 , demonstrating the extensive use of accounting information management to reduce results in these two years. 
Table 1. Mean of positive and negative discretionary accumulations that can be managed

\begin{tabular}{|c|c|c|c|c|c|c|c|c|c|c|c|}
\hline Description & 2008 & 2009 & 2010 & 2011 & 2012 & 2013 & 2014 & 2015 & 2016 & 2017 & 16,2 \\
\hline Average Positive Accruals & 0.09 & 0.11 & 0.09 & 0.05 & 0.10 & 0.09 & 0.08 & 0.09 & 0.10 & 0.12 & \\
\hline $\begin{array}{l}\mathrm{N}^{\circ} \text { of Companies with Positive } \\
\text { Accruals }\end{array}$ & 70 & 114 & 59 & 86 & 106 & 113 & 103 & 110 & 99 & 111 & 200 \\
\hline Average Negative Accruals & -0.19 & -0.17 & -0.15 & -0.08 & -0.07 & -0.10 & -0.06 & -0.07 & -0.08 & -0.06 & \\
\hline $\begin{array}{l}\mathrm{N}^{\circ} \text { of Companies with Negative } \\
\text { Accruals }\end{array}$ & 82 & 39 & 99 & 64 & 49 & 42 & 50 & 43 & 55 & 46 & \\
\hline
\end{tabular}

Source: Research data.

On the other hand, it suggests that the year 2009 and years after 2010, most companies used earnings management practices to increase reported earnings, which implies reporting more satisfactory results to users of accounting information.

In general, there is a pattern of use of earnings management practices to increase profits from 2011, a factor that can be explained by the adoption of IFRS, which began to be widely used in mid-2011 and raised the subjectivity of accountants in the choice of accounting policies. The economic and political crisis has been another important factor in Brazil, which has been a drag since the middle of 2014, which may contribute to companies' choice of using discretionary accruals to minimize the reporting of losses.

Table 2 shows the average sticky cost per year that were calculated using equations 4 and 5. The positive score of this variable reveals the existence of sticky costs in the companies' operations.

We can observe in Table 2 that in 2008, 2010, 2011, 2014, 2016 and 2017, most companies presented Negative Score in sticky costs, demonstrating that most of the organizations have adjusted their costs in a proportional way to the revenues, with fewer companies with asymmetric cost behavior. However, even though the majority of companies presented symmetrical cost behavior during these periods, it can be observed that in the years of 2008 and 2010 the average of Positive Score was higher for companies with sticky costs behavior. It may suggest that even with a smaller number of companies with such behavior, presented relevant asymmetric behavior.

Notwithstanding, in the years 2009, 2012, 2013 and 2015, most of the studied companies presented a Positive Score, proving that most organizations have not been able to adapt costs proportionally to the variations in revenues. Also, even though the majority of companies presented asymmetric behavior in costs in these periods, it was observed that only in 2015 the average Positive Score was higher in relation to the Negative Score, suggesting that even with a larger number of companies with such behavior, the intensity of the presented asymmetry is inferior to those that present symmetrical behavior in the costs.

In general, we observe that the sticky costs do not follow a pattern, as it did in the practices of earnings management. In some periods, most companies presented asymmetric behavior in costs, while in others, companies indicated a better adaptation of costs about variability in sales revenues, indicating a symmetry of costs. The seasonality of the Brazilian market can explain this result since the costs are asymmetric because their reduction does not occur in the same proportion or at the same speed as the fall in revenues. In this sense, the more seasonal market can bring greater difficulty of adherence of the costs by the organizations, since the market changes affect the establishment of strategies and goals, causing managers not to manage to reduce the costs in an equivalent way to the possible variations of the recipes. 
BBR

16,2

201

Table 2. Mean of the levels of cost asymmetry.

\begin{tabular}{|c|c|c|c|c|c|c|c|c|c|c|}
\hline Description & 2008 & 2009 & 2010 & 2011 & 2012 & 2013 & 2014 & 2015 & 2016 & 2017 \\
\hline $\begin{array}{l}\text { Positive Mean Score for } \\
\text { Asymmetry Costs }\end{array}$ & 4.52 & 0.16 & 0.45 & 0.71 & 0.21 & 0.93 & 0.19 & 1.01 & 1.19 & 0.17 \\
\hline $\begin{array}{l}\mathrm{N}^{\circ} \text { of Companies Asymmetry } \\
\text { Positive Costs }\end{array}$ & 4 & 99 & 69 & 44 & 140 & 110 & 61 & 83 & 46 & 16 \\
\hline $\begin{array}{l}\text { Negative Score Average } \\
\text { Asymmetry Costs }\end{array}$ & -2.95 & -0.68 & -0.23 & -1.08 & -0.32 & -2.63 & -0.31 & -0.14 & -0.52 & -0.20 \\
\hline $\begin{array}{l}\mathrm{N}^{0} \text { of Companies Asymmetry } \\
\text { Negative Costs }\end{array}$ & 148 & 54 & 89 & 106 & 15 & 45 & 92 & 70 & 108 & 141 \\
\hline
\end{tabular}

Source: Research data.

Moreover, since Brazil's economic crisis has created economic instability for companies, they may not be able to reduce costs in the short term, because of the need to keep various expenses in order to wait until the market slows down and investments and growth can occur.

Table 3 shows the influence of sticky costs on the level of earnings management (equation 6 ), as well as the inclusion of cost asymmetry to mitigate its possible effect on earnings management practices by Dechow, Sloan and Sweeney model (1995) (equation 7).

The results indicated by Table 3 suggest that there is a positive and significant relationship between the (asymmetric behavior of costs) and the discretionary accruals, by the coefficient of 0.0083 and with the total accumulations, by the coefficient of 0.0044 . Considering the result, we can infer that the asymmetric behavior of costs explains, at least in part, the companies' earnings management practices.

Thus, the evidence suggests that the measurement of discretionary accruals, used as proxy for earnings management, without the consideration that the asymmetric behavior of costs causes at least part of them, can cause distortions in the conclusions of studies that measure the quality of accounting information, as well as those that discuss the Agency Theory. In addition, some studies that outlined that managers present opportunistic behavior in relation to the disclosure of the accounting result may have wrongly penalized some actors, since part of the opportunistic behavior was not intentional but impacted by the asymmetric behavior of costs, which refers to an adaptation of the company's organizational activities in the face of market changes.

The result supports non-rejection of $\mathrm{H} 1$, that management of results through accounting choices is partly a result of asymmetric behavior of costs. Therefore, the study maintains that a part of the management of results may not be a consequence of the opportunistic behavior of managers, but has its origin in the changes of the operational activities, considering the decisions of market adaptations that involve cuts or maintenance of costs are necessary for the strategies and to maintain competitiveness.

Also, to add to the EM measurement model (equation 7) the asymmetric cost behavior variable has relevance to mitigate the effect of sticky costs in the estimation of discretionary accruals. The insertion of the asymmetric cost behavior variable can be useful to improve the explanatory power of models that try to capture earnings management practices.

The results complement the findings by Banker and Chen (2006), Weiss (2010), Kama and Weiss (2013) and Banker et al. (2016), who observed that sticky costs, which comes from the theoretical platform of managerial accounting, is related to the theoretical discussions of financial accounting, such as the prediction of profits (BANKER, CHEN, 2006, WEISS, 
Table 3. Summary of Equation 6 and 7 - Influence of sticky costs and control variables in the level of earnings management and inclusion of sticky costs in the Dechow model, Sloan and Sweeney (1995), respectively.

\begin{tabular}{|c|c|c|c|c|}
\hline \multirow[t]{2}{*}{ Variables } & \multicolumn{2}{|c|}{$\begin{array}{l}\text { Equation } 6-\mathrm{AD}_{\text {it }} \\
\text { Random Effect }\end{array}$} & \multicolumn{2}{|c|}{$\begin{array}{l}\text { Equation } 7-\mathrm{TA}_{i t} \\
\text { Fixed Effect }\end{array}$} \\
\hline & Coefficient & P-value & Coefficient & P-value \\
\hline SC_Score $_{\text {it }}$ & $\beta 10.0083093$ & $0.000 *$ & $\beta 30.0044597$ & $0.046^{* *}$ \\
\hline $\mathrm{TAM}_{\mathrm{it}}$ & $\beta 20.0094787$ & $0.001 *$ & & \\
\hline $\mathrm{END}_{\mathrm{it}}$ & $\beta 30.0556146$ & $0.000^{*}$ & & \\
\hline $\mathrm{ROE}_{\mathrm{i}}$ & $\beta 4-0.0018178$ & 0.561 & & \\
\hline $1 / \mathrm{A}_{i t-1}$ & & & $\alpha 3411.879$ & $0.008^{*}$ \\
\hline$\Delta \mathrm{R}_{i t}-\Delta \mathrm{CR}_{\mathrm{it}}$ & & & $\beta 10.0471945$ & 0.158 \\
\hline $\mathrm{PPE}_{i t}$ & & & $\beta 2-0.0059414$ & 0.836 \\
\hline _Constant & -0.1228444 & 0.006 & 0.0339812 & 0.003 \\
\hline R Overall/R Within & \multicolumn{2}{|c|}{0.1416} & \multicolumn{2}{|c|}{0.0093} \\
\hline Prob $>$ chi2 & \multicolumn{2}{|c|}{$0.0000 *$} & \multicolumn{2}{|c|}{$0.0123 * *$} \\
\hline Breusch-Pagan's LM & \multicolumn{2}{|c|}{$0.0002 *$} & \multicolumn{2}{|c|}{$0.0000^{*}$} \\
\hline Chow Test & \multicolumn{2}{|c|}{$0.0000 *$} & \multicolumn{2}{|c|}{$0.0000^{*}$} \\
\hline Hausman Test & \multicolumn{2}{|c|}{0.1816} & \multicolumn{2}{|c|}{$0.0039 *$} \\
\hline Company, Year and Sector Effect & \multicolumn{2}{|c|}{ Yes } & \multicolumn{2}{|c|}{ Yes } \\
\hline $\mathrm{N}$ & \multicolumn{2}{|c|}{1540} & \multicolumn{2}{|c|}{1531} \\
\hline
\end{tabular}

Equation 6: Dependent variable: $\mathrm{AD}_{\text {it }}$ - level of earnings management observed through equation 3; Independent variables: SC_Score ${ }_{i t}$ - level of cost asymmetry (Sticky Costs) observed by means of equation 5; TAM $_{\text {it }}$ - size of the company, represented by total logarithmic assets; END $_{\text {it }}$ - company's indebtedness, represented by the sum of current liabilities, plus non-current liabilities, devided by total assets; $\mathrm{ROE}_{\mathrm{it}}$ - return on Shareholders' Equity. Equation 7: Dependent variable: $\mathrm{TA}_{i t}$ - accruals of company $i$ in period $t$, weighted by total assets at the end of the period $t_{-}$; Independent variables: Ait ${ }_{-1}$ total assets of the company at the end of the period $t_{-1} ; \Delta \mathrm{R}_{i t}-\Delta \mathrm{CR}_{\mathrm{it}}-$ change in net revenues of company $i$ of period $t$ for the period $t_{-l}$, weighted by total assets at the end of the period $t_{-1}$ less the change in accounts receivable from company $i$ of period $t$ for the period $t_{-1}$, weighted by total assets at the end of the period $t_{-l} ; \mathrm{PPE}_{i t}$ - total fixed assets and deferred or intangible assets of company $i$ at the end of period $t$, weighted by total assets at the end of the period $t_{-1}$; $\mathrm{SC}_{-} \mathrm{Score}_{\text {it }}-$ level of cost asymmetry (Sticky Costs) observed by means of equation $5 .{ }^{*}$ Significant at $1 \%$; ** Significant at $5 \%$. Source: Research data.

2010), profit goals (KAMA, WEISS, 2013), accounting conservatism (BANKER et al., 2016) and, according to this study, with earnings management practices.

Moreover, the results indicate that larger firms (TAM) are positively related to discretionary accruals, confirming the inference by Watts and Zimmerman (1990) and Leuz that larger firms may be interested in managing their results to be under more public scrutiny and under the eyes of regulators, who seek to create new taxes and fees for the most profitable organizations.

Therefore, we observed that the companies with the highest indebtedness (ND) are positively related to discretionary accruals, contrary to the inferences by Bushman et al. (2003), that indebted companies would have better quality accounting information due to the need for third-party capital. The results of this study suggest the opposite, that the 
indebted companies due to the need for greater third-party capital would tend to manage their results by seeking the maintenance of financing agreements and even their possible extension, as well as avoiding breaches of contractual covenants.

In order to deepen the results of equation 7, we present the coefficients R2 and residues of the Dechow, Sloan, and Sweeney (1995) model in Table 4 with and without the inclusion of the sticky costs variable. In this stage, the equations were calculated by sector and year and after, we extracted the coefficients final average.

Table 4. Summary of Equation 7 - Analysis of the coefficients, $\mathrm{R}^{2}$ and residues of the model by Dechow, Sloan and Sweeney (1995), with and without inclusion of the sticky costs variable.

\begin{tabular}{|c|c|c|}
\hline Variables & $\begin{array}{c}\text { Equation } 7 \\
\text { Without SC_Score }_{\text {it }}\end{array}$ & $\begin{array}{c}\text { Equation } 7 \\
\text { With SC_Score }{ }_{i t}\end{array}$ \\
\hline & Average years and sectors & Average years and sectors \\
\hline Coefficient $1 / \mathrm{A}_{i t-1}$ & -7701.805 & -2398.051 \\
\hline Coefficient $\Delta \mathrm{R}_{i t}-\Delta \mathrm{CR}_{\mathrm{it}}$ & -0.036 & -0.027 \\
\hline Coefficient PPE $\mathrm{P}_{i t}$ & 0.068 & 0.056 \\
\hline Coefficient SC_Score $_{\text {it }}$ & - & 0.038 \\
\hline Negative Residues & -0.072 & -0.070 \\
\hline Quantity of Remarks negative residues & 776 & 751 \\
\hline Positive Residues & 0.075 & 0.068 \\
\hline Number of Positive Residual Remarks & 755 & 780 \\
\hline $\mathrm{R}^{2}$ & 0.291 & 0.307 \\
\hline $\mathrm{N}$ & 1531 & 1531 \\
\hline
\end{tabular}

Dependent variable: $\mathrm{TA}_{i t}$ - accruals of company $i$ in period $t$, weighted by total assets at the end of the period $t_{-l}$; Independent variables: $\mathrm{A}_{i t-1}$ - total assets of the company at the end of the period $t_{-l} ; \Delta \mathrm{R}_{i t}-\Delta \mathrm{CR}_{\mathrm{it}}^{-1}$ - change in net revenues of company $i$ of period $t$ for period $t_{-1}$, weighted by total assets at the end of period $t_{-1}$, less the change in accounts receivable from company $i$ of period $t$ for period $t_{-l}$, weighted by total assets at the end of period $t_{-l} ; \mathrm{PPE}_{i t}$ - total fixed assets and deferred or intangible assets of company $i$ at the end of period $t$, weighted by total assets at the end of the period $t_{-1}$; SC_Score it $_{-}$level of cost asymmetry (Sticky Costs) observed by means of equation 5.

Source: Research data.

We observe in Table 4 that the insertion of the asymmetric behavior variable of the costs in the regression model used for the estimation of discretionary accruals caused a reduction in all the coefficients. This result shows that the asymmetric behavior of costs provoked an adaptation in the other explanatory variables of the total accumulations. Therefore, as the Dechow, Sloan, and Sweeney (1995) model uses regression residues to estimate the level of discretionary accruals of firms, we found the asymmetric cost behavior to reduce the mean of negative and positive residues.

Thus, the results indicate that residues from the model that do not include the asymmetric cost behavior variable do not represent earnings management practices (opportunistic behavior) since, with the inclusion of the asymmetric behavior variable, there was a reduction in both negative and positive waste. Also, without considering the asymmetry of costs, more companies were managing the result to reduce their profits. With the inclusion of sticky costs, we observed that most companies managed results to increase profit. 
This result may indicate that part of the management of results that is done to reduce profits, in fact, would be the sticky costs itself since it recognizes more costs when there are bigger sales, which reduces the profit and could be confused with the earnings management to reduce profits. We confirm this result by observing the mean of negative residues before and after the inclusion of the sticky costs variable, and without considering this variable, the mean of negative residues was higher when compared to the model that controls sticky costs.

Finally, there was an increase in the explanatory power of the model that inserts the variable of asymmetric cost behavior, although only around 1\%. It was relevant to consider the behavior of cost adaptation to changes in real activities in determining the total usable accumulations, in order to minimize the noise resulting from residues, which measures the discretionary accumulations. In general, the findings prove the need for using the sticky costs variable in the estimation models of discretionary accruals.

\section{DISCUSSION AND CONCLUSION}

When testing the influence of sticky costs on EM, the results indicated that sticky costs had a positive impact on discretionary accruals. Therefore, we concluded that the sticky costs caused part of earnings management and, therefore, the discretionary accruals estimation models may present inconsistency in the results that determine the opportunistic behavior of managers and companies.

Until then, research used to analyze the EM as being caused only by opportunistic practices of managers, not considering the company's usual practices regarding the adherence of organizational resources, such as the case of sticky costs. Thus, observing that earnings management models have not controlled the effect of cost asymmetry, consistent results have been found to suggest that future studies will neutralize the influence of sticky costs.

We also concluded that without considering the sticky costs, the measurement of earnings management practices could super evaluate the opportunistic behavior of managers, increasing the agency conflicts between managers and shareholders. Also, it is considered that this research used the propositions by Banker et al. (2016); however, focusing on earnings management practices. For this purpose, the results offer a proposal to correct the problems of sticky costs in the estimation of discretionary accruals established models, a proxy for earnings management practices, as in the case of Dechow, Sloan, and Sweeney (1995).

The evidence from Banker and Chen (2006), Weiss (2010), Chen, Lu and Sougiannis (2012), Kama and Weiss (2013) and Banker et al. (2016) on the relationship of sticky costs with financial accounting, in that it interferes with the value of total accruals, which are used to determine discretionary accruals in the analysis of earnings management practices. We suggested that, although earnings management does not consider the profit reported as an intervening variable, it can also be affected indirectly by the allocation of production costs and, therefore, by the sticky costs.

This result offers contributions to analysts, investors, auditors, financial institutions, minority, and majority shareholders, noting that not all earnings management is due to opportunistic behavior since the adjustment of costs to changes in revenues could explain it in part. Thus, companies with a fall in sales that cannot reduce their costs in the same proportion may present the earnings management evidence that refers to the opportunist behavior of the manager, when in fact, it is partly just an asymmetry of costs. 
BBR

16,2

The results of the present research provide important conclusions that contribute to the area of managerial accounting and financial accounting; however, the subject has not been exhausted in the present study, since it presents limitations such as EM analysis only by aggregate accumulations and using a model only. In the same way, the sticky costs were analyzed only by the prism of a model. However, such limitations do not compromise results, as they stem from researchers' choices, and provide new insights into the association between these two areas of research.

Therefore, we suggest as future research, the deepening of the analysis between sticky costs with EM, through other models not investigated in the present study, such as EM for specific accounts, real EM, sticky costs based on traditional models and in differentiated samples. We also suggest as future research that studies develop the proposition of new models that consider the adherence of the quality of the accounting information to the asymmetric behavior of costs.

\section{REFERENCES}

ANDERSON, M. C.; BANKER, R. D.; JANAKIRAMAN, S. N. Are selling, general, and administrative costs "sticky"? Journal of Accounting Research, v. 41, n. 1, p. 47-63, 2003.

BANKER, R. D.; BASU, S.; BYZALOV, D.; CHEN, J. Y. The confounding effect of cost stickiness on conservatism estimates. Journal of Accounting and Economics, v. 6, n. 1, p. 203-220, 2016.

BANKER, R. D.; BYZALOV, D. Asymmetric cost behavior. Journal of Management Accounting Research, v. 26, n. 2, p. 43-79, 2014.

BANKER, R. D.; CHEN, L. Predicting earnings using a model based on cost variability and cost stickiness. The accounting review, v. 81, n. 2, p. 285-307, 2006.

BAPTISTA, E. M. B. Análise do perfil das empresas brasileiras segundo o nível de gerenciamento de resultados. 303 f. Tese (Doutorado em Administração) - Programa de Pós-Graduação em Administração, Universidade Federal do Rio Grande do Sul, 2008.

BUSHMAN, R.; CHEN, Q.; ENGEL, E.; SMITH, A. (2004). Financial accounting information, organizational complexity and corporate governance systems. Journal of Accounting and Economics, v. 37, n. 2, p. 167-201, 2004.

CALLEJA, K.; STELIAROS, M.; THOMAS, D. C. A note on cost stickiness: Some international comparisons. Management Accounting Research, v. 17, n. 2, p. 127-140, 2006.

CANNON, J. N. Determinants of "sticky costs": An analysis of cost behavior using United States air transportation industry data. The Accounting Review, v. 89, n. 5, p. 1645-1672, 2014.

CHEN, C. X.; LU, H.; SOUGIANNIS, T. The agency problem, corporate governance, and the asymmetrical behavior of selling, general, and administrative costs. Contemporary Accounting Research, v. 29, n. 1, p. 252-282, 2012.

DECHOW, P. M.; SLOAN, R. G.; SWEENEY, A. P. Detecting earnings management. The Accounting Review, p. 193-225, 1995.

DOYLE, J. T.; GE, W.; MCVAY, S. Accruals quality and internal control over financial reporting. The Accounting Review, v. 82, n. 5, p. 1141-1170, 2007.

HE, D.; TERUYA, J.; SHIMIZU, T. Sticky selling, general and administrative cost behavior and its changes in Japan. Global Journal of Business Research, v. 4, n. 4, p. 1-10, 2010.

HEALY, P. M.; WAHLEN, J. M. A review of earnings management literature and its implications for standard setting. Accounting Horizons, v. 13, p. 365-383, 1999.

JONES, J. J. Earnings management during import relief investigations. Journal of Accounting Research, p. 193-228, 1991.

KAMA, I.; WEISS, D. Do earnings targets and managerial incentives affect sticky costs?. Journal of Accounting Research, v. 51, n. 1, p. 201-224, 2013.

KHAN, M.; WATTS, R. L. Estimation and empirical properties of a firm-year measure of accounting conservatism. Journal of accounting and Economics, v. 48, n. 2-3, p. 132-150, 2009. 
LEUZ, C. IAS versus US GAAP: information asymmetry-based evidence from Germany's new market. Journal of Accounting Research, v. 41, n. 3, p. 445-472, 2003.

LEUZ, C.; NANDA, D.; WYSOCKI, P. Investor protection and earnings management: An international comparison. Journal of Financial Economics, v. 69, n. 3, p. 505-527, 2003.

MALIK, M. A review and synthesis of 'cost stickiness' literature. Social Science Research Network, p. $1-41,2012$.

MARTINEZ, A. L. Minimizando a variabilidade dos resultados contábeis: estudo empírico do income smoothing no Brasil. Revista Universo Contábil, v. 2, n. 1, p. 09-25, 2006.

PORPORATO, M.; WERBIN, E. M. Active cost management in banks: evidence of sticky costs in Argentina, Brazil and Canada. AAA Management Accounting Section (MAS) Meeting Paper. Disponível em: http://dx.doi. org/10.2139/ssrn.1659228, 2010.

SCHIPPER, K. Commentary on earnings management. Accounting Horizons, v. 3, n. 4, p. 91-102, 1989.

SUBRAMANIAM, C.; WEIDENMIER, M. L. Additional Evidence on the Sticky Behavior of Cost. In: M. J. Neeley School of Business. Texas Christian University, 2003.

WATTS, R. L.; ZIMMERMAN, J. L. Positive accounting theory: a ten-year perspective. Accounting review, p. 131-156, 1990.

WEISS, D. Cost behavior and analysts' earnings forecasts. The Accounting Review, v. 85, n. 4, p. 1441$1471,2010$.

We declare that there is no conflict of interest and also that all authors contributed to the research and the article. 